\title{
EFEKTIVITAS LAYANAN BIMBINGAN KLASIKAL DENGAN E-LEARNING MELALUI PEMBELAJARAN BERBASIS PROJECT UNTUK MENINGKATKKAN RESILIENSI KEPALA SEKOLAH DI MASA COVID-19
}

\author{
Ibnu Athiyah \\ PPPPTK Penjas dan BK, Kementerian Pendidikan Kebudayaan Riset dan Teknologi \\ e-mail: ibnup4tkbk@gmail.com
}

https://doi.org/10.36052/andragogi.v9i1.218

Diterima: 1 Mei 2021 | Disetujui: 2 Juni 2021 | Dipublikasikan: 30 Juni 2021

\begin{abstract}
Abstrak
Penelitian ini bertujuan untuk menguji efektivitas layanan bimbingan klasikal berbasis pembelajaran proyek untuk meningkatkan resiliensi kepala sekolah taman kanak-kanak di Jakarta Timur. Jenis penelitian ini adalah penelitian experimen dengan one group pretest-posttets design. Subjek penelitian kepala sekolah taman kanak-kanak di Jakarta Timur. Populasi dalam penelitian ini adalah 30 orang. Teknik sampling yang digunakan sampling jenuh sebanyak 30 orang. Penelitian dilakukan novemberdesember 2020. Instrumen penelitian yang digunakan adalah skala resiliensi yang disusun peneliti sendiri, dengan validitas 0,308 (Pearson Product Moment) dan reliabilitas 0,811 (Alpha Cronbach), uji normalitas data dengan uji Shapiro-Wilk $(0,318>0,05)$. Teknik Analisis data dengan menggunakan statistik parametrik dengan uji paired sample $t$-test dengan $(t=.-36,870, p<0,05)$. Hasil penelitian memberikan pemahaman bahwa layanan bimbingan klasikal dengan pembelajaran berbasis proyek efektif meningkatkan resiliensi kepala sekolah taman kanak-kanak.
\end{abstract}

Katakunci: bimbingan klasikal, pembelajaran berbasis proyek, resiliensi.

\begin{abstract}
[E-LEARNING BASED CLASSICAL COUNSELING SERVICE EFFECTIVENESS THROUGH PROJECTBASED LEARNING TO INCREASE THE RESILIENCE OF KINDERGARTEN PRINCIPALS IN THE TIME OF COVID-19]. This study aimed to improve project learning-based classical service supervision to increase the resilience of kindergarten principals in East Jakarta. This type of research was experimental research with one group pretest-posttets design. The research subject was the principal of kindergarten in East Jakarta. The population in this study were 30 people. The sampling technique used was saturated sampling of 30 people. The research was conducted from November to December 2020. The research instrument used was a resilience scale compiled by the researchers themselves, with a validity of 0.308 (Pearson Product Moment) and 0.811 reliability (Alpha Cronbach), data normality test with the Shapiro test. -Wilk $(0.318>0.05)$. The data analysis technique used parametric statistics with paired sample $t$-test with $(t=.-36.870, p<0.05)$. The results of the study provided an understanding that classical services with project-based learning are effective in increasing the resilience of kindergarten principals.
\end{abstract}

Keywords: Classical Guidance, Project Based Learning, Resilience

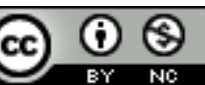

This work is licensed under a Creative Commons Attribution-NonCommercial 4.0 International License 


\section{PENDAHULUAN}

V irus Covid-19 telah menjadi wabah seluruh dunia, virus yang telah mematikan banyak manusia ini menyebabkan aktivitas manusia terganggu dari normal menjadi new normal. Perubahan drastis telah terjadi diberbagai aspek kehidupan, salah satu contoh perubahan dalam keseharian adalah memakai masker, mencuci tangan pakai sabun dan air mengalir, menjaga jarak, menjauhi kerumunan, serta membatasi mobilisasi dan interaksi (5M). Bagi lembaga diklat adanya kebijakan 5M untuk memutus rantai penyebaran covid-19, maka seluruh pembelajaran dari jenjang guru dan tenaga kependidikan tidak lagi dilakukan secara tatap muka dan bertemu secara langsung di ruang kelas.

Menurut Mastura \& Rustan (2020), setelah adanya pandemi covid-19 interaksi yang terjadi antara siswa dan guru dilakukan dalam ruang virtual yang terbatas. Hal ini juga berlaku bagi widyaiswara (pelatih) dengan peserta diklat. Oleh karena itu, widyaisara harus memiliki kemampuan untuk menciptakan suasana kelas yang kondusif, pembelajaran yang kreatif serta inovatif melalui aplikasi pembelajaran online (daring).

Berdasarkan studi pendahuluan, diketahui terdapat permasalahan yang mengindikasikan beberapa kepala sekolah kurang memiliki resiliensi. Untuk memperkuat benar adanya permasala-han tersebut, peneliti melalukan survei berupa penyebaran angket kepada kepala sekolah. Hasil pengelohan angket menunjukkan bahwa kepala sekolah memiliki tingkat resiliensi rendah dalam mengikuti pelatihan. Issacson (2002:4) menyatakan bahwa resiliensi berarti kemampuan untuk mengatasi kesulitan traumatis. Selain itu juga untuk merespon tekanan hidup sehari-hari secara fleksibel.

Salah satu model pembelajaran yang dapat digunakan oleh pendidik (pelatih) dan dianggap mampu membentuk keterampilan kepala sekolah melalui pembelajaran berbasis proyek. Dengan pembelajaran ini kepala sekolah akan menghadapi dan melakukan pengalaman langsung dalam belajar dengan menggunakan potensi yang dimiliki untuk memiliki resiliensi yang baik. Kegiatan pembelajaran dalam pelatihan ini untuk mengukur kompetensi pendidik sebagai kepala sekolah di satuan pendidikan tempatnya bekerja melalui berbagai kegiatan, sehingga perannya sebagai kepala sekolah diakui oleh negara. Kegiatan pembelajaran ini di-setting melalui bimbingan klasikal di mana semua kepala sekolah mempunyai 1 pengajar di kelas.

Kemudian di dalam bimbingan konseling terdapat beberapa layanan yang bisa digunakan dalam resiliensi kepala sekolah, salah satu cara adalah melalui layanan bimbingan klasikal. Menurut Makhrifah \& Nuryono, (2014) mengemukakan bimbingan klasikal merupakan suatu layanan bimbingan dan konseling yang diberikan kepada siswa oleh guru bimbingan \& konseling (Guru BK) atau konselor kepada sejumlah siswa dalam satuan kelas yang dilaksanakan di dalam kelas. Hal ini sepaham dengan yang ditegaskan oleh Winkel dan Hastuti (2010) bimbingan klasikal merupakan layanan bimbingan yang diberikan kepada siswa dalam jumlah satuan kelas atau suatu layanan bimbingan yang diberikan oleh guru bimbingan dan konseling kepada sejumlah peserta didik dalam satuan kelas yang dilaksanakan di ruang kelas. Sedangkan di sisi lain bimbingan klasikal adalah bimbingan yang dilakukan kepada seluruh siswa didalam kelas atau gabungan dari beberapa kelas (Supriyo, 2010). Sedangkan menurut Budiman (2017) bimbingan klasikal juga dapat diartikan sebagai bimbingan yang dimaksudkan untuk sebuah bantuan bagi seluruh peserta didik dalam satuan kelas. Bimbingan klasikal ini bersifat preventif sehingga peserta didik mampu menghindari munculnya masalah dari perilakunya sendiri. Dalam penelitian ini yang dimaksud peserta didik dalam bimbingan klasikal adalah kepala sekolah. Berdasarkan pendapat ahli di atas dapat disimpulkan layanan bimbingan klasikal adalah bantuan bimbingan konseling yang diberikan kepada kepala sekolah dengan menggunakan segala potensi dalam melaksanakan pembelajaran yang diberikan di dalam kelas.

Dalam lingkup kegiatan pelatihan ini layanan bimbingan klasikal berbasis e-learning 
merupakan bantuan bimbingan konseling yang diberikan kepada sejumlah kepala sekolah di kelas online dalam bentuk tatap muka antara widyaiswara (pelatih) dan kepala sekolah. Kemudian untuk memudahkan pemahaman pembaca tentang e-learning, peneliti jabarkan e-learning dari para ahli. Dong (dalam Kamarga, 2002) mendefinisikan e-learning sebagai kegiatan belajar asynchronous melalui perangkat elektronik komputer yang memperoleh bahan belajar yang sesuai dengan kebutuhannya.

Menurut Numiek Sulistyo Hanum (2013) e-learning merupakan salah satu bentuk model pembelajaran yang difasilitasi dan didukung pemanfaatan teknologi informasi dan komunikasi. Silahuddin (2015) e-learning adalah bentuk pembelajaran konvensional yang dituangkan dalam format digital melalui teknologi internet. E-lerning pada saat sekarang ini dapat dijadikan sebagai salah satu pendekatan dalam pendidikan dan juga bisa menjadi sebagai media strategis dan metode pembelajaran aktif, kreatif, inovatif dalam menciptakan manusia yang berilmu dan beriman mampu mengatasi tantangan global serta mampu mengimplementasikannya dalam kehidupan sehari-hari. Menurut Ade Kusmana (2015) e-learning merupakan suatu teknologi informasi yang relatif baru di Indonesia, $e$ learning terdiri atas dua bagian yaitu 'e-' yang merupakan singkatan dari electronic dan learning yang berarti pembelajaran, jadi $e$ learning berarti pembelajaran dengan menggunakan jasa bantuan perangkat elektronik, khususnya perangkat komputer

E-learning disebut pula dengan online course. Berdasarkan pendapat para ahli di atas dapat disimpulkan e-learning adalah media aplikasi online (internet) yang dipakai dalam pembelajaran jarak jauh dengan memanfaatkan teknologi komunikasi dan informasi untuk mencapai tujuan pembelajaran.

Penerapan E-learning dilakukan karena penyebaran virus covid-19 masih tinggi dan belum ada vaksin anti-covid saat itu. Oleh karena itu kegiatan ini perlu diselenggarakan agar segenap potensi yang dimiliki kepala sekolah sebagai peserta pelatihan dapat berkembang secara optimal dalam penguasaan materi pelatihan.

Layanan bimbingan klasikal merupakan bantuan bimbingan konseling yang diberikan kepada sejumlah guru di kelas pelatihan dalam bentuk tatap muka antara widyaiswara (pelatih) dan kepala sekolah taman kanak-kanak. Kegiatan ini perlu diselenggarakan agar segenap potensi yang dimiliki kepala sekolah sebagai peserta dalam pendidikan dan pelatihan ini dapat berkembang secara optimal dalam penguasaan materi pelatihan. Penelitian ini penting untuk dilakukan agar terciptanya resiliensi yang baik pada kepala sekolah, secara individu ataupun klasikal di dalam proses belajar dan setelah kembali ke tempat kerja masing-masing. Kemudian untuk tercapainya resiliensi melalui bimbingan klasikal, perlu digunakan metode supaya memudahkan dalam pelaksanaannya, salah satu metode tersebut adalah pembelajaran berbasis proyek.

Menurut Goodman dan Stivers (2010) mendefinisikan project based learning merupakan pendekatan pengajaran yang dibangun di atas kegiatan pembelajaran dan tugas nyata yang memberikan tantangan bagi peserta didik yang terkait dengan kehidupan sehari-hari untuk dipecahkan secara berkelompok. Sepaham dengan pendapat di atas menurut Afriana (2015), pembelajaran berbasis proyek merupakan model pembelajaran yang berpusat pada peserta didik dan memberikan pengalaman belajar yang bermakna bagi peserta didik. Pengalaman belajar peserta didik maupunkonsep dibangun berdasarkan produk yang dihasilkan dalam proses pembelajaranberbasis proyek. Di sisi lain pendapat Grant (2002) mendefinisikan project based learning atau pembelajaran berbasis proyek merupakan model pembelajaran yang berpusat pada peserta didik untuk melakukan suatu investigasi yang mendalam terhadap suatu topik. Peserta didik secara konstruktif melakukan pendalaman pembelajaran dengan pendekatan berbasis riset terhadap permasalahan dan pertanyaan yang berbobot, nyata, dan relevan.

Sedangkan Made Wena (dalam Lestari, 2015) menyatakan bahwa model project based 
learning adalah model pembelajaran yang memberikan kesempatan kepadapendidik untuk mengelola pembelajaran di kelas dengan melibatkan kerja proyek. Kerja proyek merupakan suatu bentuk kerja yang memuat tugas-tugas kompleks berdasarkan kepada pertanyaan dan permasalahan yang sangat menantang dan menuntun peserta didik untuk merancang, memecahkan masalah, membuat keputusan, melakukan kegiatan investigasi, serta memberikan kesempatan peserta didik untuk bekerja secara mandiri.

Berdasarkan pendapat ahli di atas dapat disimpulkan pembelajaran berbasis proyek adalah pembelajaran yang memandirikan peserta didik untuk mengalami pembelajaran yang menantang dengan melakukan investigasi dan analisis untuk diselesaikan dalam bentuk penugasan. Berdasarkan pemaparan di atas, maka peneliti menentukan rumusan masalah peneliti ini yaitu apakah layanan bimbingan klasikal berbasis e-learning melalui pembelajaran berbasis proyek efektif meningkatkan resiliensi kepala sekolah taman kanak-kanak di jakarta timur?

Tujuan penelitian ini adalah untuk mengetahui keefektifan layanan bimbingan klasikal berbasis e-learning dengan pembelajaran berbasis proyek dalam meningkatkan resiliensi kepala sekolah taman kanak-kanak di Jakarta Timur.

\section{METODE PENELITIAN}

Penelitian ini menggunakan metode eksperimental dengan one grup pretest-postest design. Subjek penelitian ini adalah kepala sekolah taman kanak-kanak di Jakarta Timur. Populasi penelitian sebanyak 30 orang, kemudian teknik sampel yang digunakan sampling jenuh sebanyak 30 orang. Instrumen penelitian yang digunakan adalah skala resiliensi dengan validitas 0,308 (Pearson Product Moment) dan diperoleh nilai reliabilitas 0,811 (Alpha Cronbach), hasil uji normalitas data dengan uji Shapiro-Wilk (Dameis dan Anwar. 2017) sebesar $(0,318>0,05)$. Teknik analisis data dengan menggunakan statistik parametrik, kemudian uji hipotesis menggunakan paired sample t- test.

\section{TEMUAN DAN PEMBAHASAN}

\section{Temuan}

Berdasarkan hasil penelitian resilensi kepala sekolah TK yang peneliti lakukan selama kegiatan pendidikan dan pelatihan diperoleh data yang disajikan dalam bentuk grafik berikut:

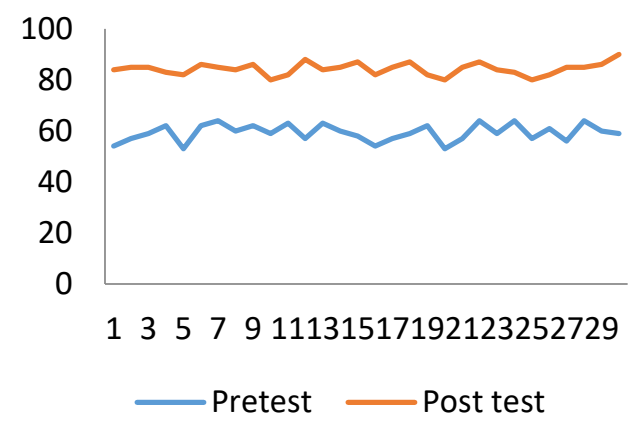

Berdasarkan grafik 1.1 di atas, ada perbedaan skor resilensi kepala sekolah TK sebelum dan sesudah diberikan layanan bimbingan klasikal dengan pembelajaran berbasis proyek. Pada grafik, skor resiliensi kepala sekolah TK Telah mengalami perubahan yaitu adanya peningkatan. Kemudian untuk mengetahui sebaran data pada suatu kelompok data tertentu sebelum dan susudah diberikan layanan bimbingan klasikal dengan pembelajaran berbasis proyek. Dilakukan uji normalitas data resiliensi kepala sekolah TK yaitu

Tabel 1.1 uji normalitas sebelum dan susudah pengambilan keputusan studi lanjut

\begin{tabular}{lllll}
\hline \multicolumn{5}{c}{ Tests of Normality } \\
\hline \multicolumn{5}{c}{ Shapiro-Wilk } \\
\hline \multirow{3}{*}{ Sebelum } & Sesudah & Statistic & df & Sig. \\
& Sebelum & .942 & 30 & .102 \\
& Sesudah & .960 & 30 & .318 \\
\hline
\end{tabular}

Berdasarkan hasil tabel 1.1 di atas dan karena jumlah sampel peneltian ini 30 , artinya di bawah 50, maka peneliti memakai hasil uji normalitas Shapiro-Wilk. Maka berdasarkan tinjauan dari hasil normalitas Shapiro-Wilk menunjukan nilai signifikan $0,318>0,05$ artinya sampel penelitian berasal dari populasi yang berdistrusi normal. 


\section{Resiliensi}

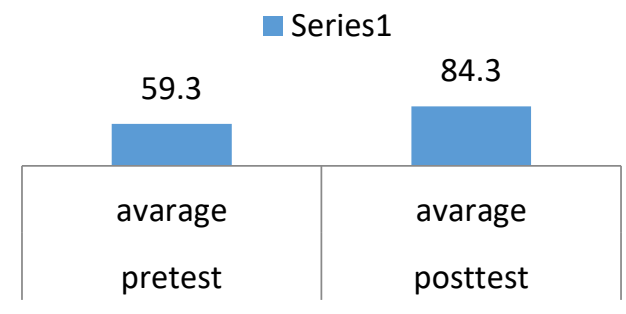

Berdasarkan grafik 1.2 di atas menunjukan bahwa capaian rata-rata skor resilensi, jika ditinjau berdasarkan selisih rata-rata sebelum dan sesudah diberikan intervensi layanan bimbingan klasikal pembelajaran berbasis proyek, dengan menggunakan rumus 02-01, maka capaian rata-rata skor kepala sekolah taman kanak-kanak mengalami kenaikan yaitu 24,07 . Hal ini menunjukkan bahwa ada perbedaan rata-rata skor resiliensi kepala sekolah taman kanakkanak.

Kemudian untuk mengetahui hasil dari hipotesis penelitian, berdasarkan tabel $1.2 \mathrm{di}$ atas diperoleh hasil statistik uji Paired Sample $T$ Test (Uji T Dua Sampel Berkorelasi) signifikan dengan nilai uji statistik $-36,870$. Hal ini dapat dilihat dari probabilitas $<0.05$. Pada uji statistik di atas pada kolom Sig. (2-tailed) untuk uji dua sisi tertera angka .000. Maka dapat dikatakan bimbingan klasikal dengan pembelajaran berbasis proyek efektif meningkatkan resiliensi kepala sekolah taman kanak-kanak.

\section{Pembahasan}

Berdasarkan hasil penelitian menunjukkan perbedaan tingkat resiliensi kepala sekolah sebelum dan sesudah mendapatkan layanan bimbingan klasikal berbasis e-learning dengan pembelajaran berbasis proyek. Secara rata-rata skor sesudah diberikan intervensi layanan bimbingan klasikal pembelajaran berbasis proyek diperoleh rata-rata lebih tinggi dari sebelum diberikan intervensi yaitu 24,07 artinya ada peningkatan resiliensi kepala sekolah taman kanak-kanak di Jakarta Timur itu penting dalam mengikuti pembelajaran dan diharuskan mengerjakan tugas-tugas yang harus diselesaikan secara mandiri oleh kepala sekolah taman kanak-kanak dalam masa Covid19 melalui pembelajaran e-learning. Penyebaran covid-19 belum mereda dari belahan bumi, pembelajaran yang sebelumnya menggunakan tatap muka, mau tidak mau harus dilakukan melalui pembelajaran online atau e-learning.

Hasil penelitian awal tingkat resiliensi kepala sekolah taman kanak-kanak berada tingkat rendah hal ini dibuktikan pada hasil penelitian yaitu 59,3\%. Tentunya ini membutuhkan solusi yang terukur, karena kepala sekolah tidak selalu mengikuti pelatihan untuk mengukur kompetensinya. Apalagi saat ini masih masa covid-19, jadi dipikirkan juga supaya kegiatan pembelajaran ini tetap berjalan. Untuk itu peneliti menggunakan pembelajaran online atau dikenal e-learning. Penggunaan e-learning telah dilakukan oleh penelitian sebelumnya dengan judul penelitian komponen pengem-bangan e-learning, hasil penelitian mengungkapkan bahwa mengembang-kan e-learning dibutuhkan

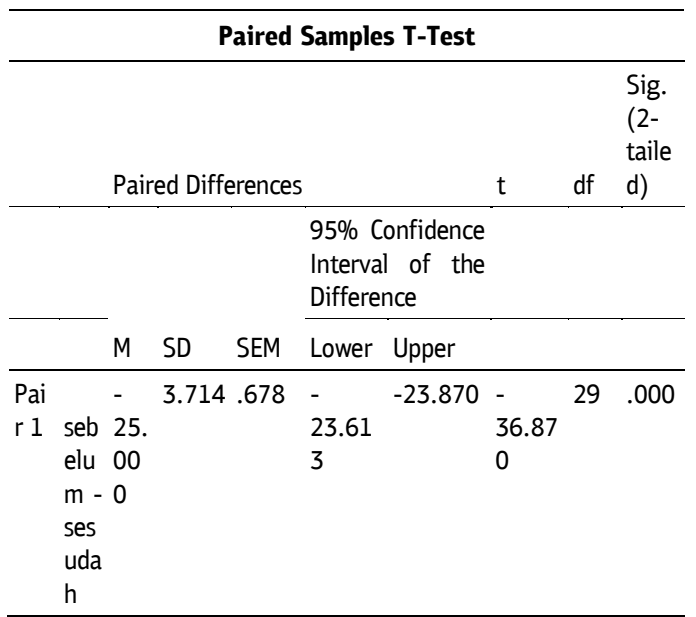

pengem-bangan yang sistematik dimulai dengan inventarisasi dan analisis kondisi yang ada, peninjauan keilmuan, sejarah pengembangan desain yang sejenis dan karakteristik populasi sebelum dikembangkannya e-learning.

Pengembangan e-learning secara sistematik membantu untuk mempertahankan kualitas e-learning yang dikembangkan agar memuaskan. Penelitian lain mendukung penggunakan e-learning efektif dalam pembalajaran. Hal ini didukung penelitian tentang e-learning telah dilakukan oleh Numiek Sulistyo Hanum (2013), judul penelitian. Keefektifan E-Learning Sebagai Media 
Pembelajaran (Studi Evaluasi Model Pembelajaran E-Learning SMK Telkom Sandhy Putra Purwokerto). Hasil penelitian menunjukkan pelaksanaan pembelajaran $e$ learning sebagai media pembelajaran di SMK Telkom Sandhy Putra Purwokerto secara keseluruhan cukup efektif dengan tingkat kecenderungan sebesar 77,27\%.

Hasil penelitian mengungkapkan bahwa model pembelajaran dengan kelas virtual ( $e$ learning) merupakan sebuah terobosan baru di bidang pengajaran dan pembelajaran, karena mampu meminimalkan perbedaan cara mengajar dan materi, sehingga memberikan standar kulitas pembelajaran yang lebih konsisten, Sistem e-Learning adalah mutlak diperlukan untuk mengantisipasi perkembangan jaman dengan dukungan teknologi informasi dimana semua menuju ke era digital, baik mekanisme maupun konten.

Kemudian berdasarkan hasil penelitian sebelumnya yang berkaitan dengan judul penelitian tentang bimbingan klasikal dengan pembelajaran berbasis proyek telah dilakukan oleh Wirda Hanim, Michiko Mamesah, Rani Romatua Anzelyna. (2018) dengan judul penelitian pengaruh bimbingan klasikal dengan model project based learning untuk meningkatkan tanggung jawab siswa (Studi Eksperimen Siswa Kelas X II Audio Video 2 SMKN 5 Jakarta). Penelitian ini bertujuan mengetahui pengaruh model Project Based Learning dalam bimbingan klasikal untuk meningkatkan tanggung jawab siswa kelas XII Jurusan Audio Video di SMKN 5 Jakarta. Hasil penelitian menunjukkan bahwa rata-rata peningkatan tanggung jawab siswa yang mendapatkan bimbingan klasikal dengan menggunakan model Project Based Learning lebih besar, dibandingkan rata-rata peningkatan tanggung jawab siswa yang tidak mendapatkan bimbingan klasikal dengan menggunakan model Project Based Learning.

Hal ini sejalan dengan penelitian yang telah dilakukan oleh Entin Martini, Wahyu Nanda Eka Saputra, Abdul Malik. (2018) dengan judul penelitian peningkatan Ketrampilan Eksplorasi Karir Melalui Bimbingan Klasikal Teknik Project Based Learning Pada Siswa Kelas X BDP 3 Di SMK Negeri 1 Kebumen.
Hasil penelitian mengungkapkan ketrampilan eksplorasi karir siswa meningkat melalui bimbingan klasikal teknik project based learning pada siswa kelas X BDP 3 Di SMK Negeri 1 Kebumen.

Sepaham dengan pendapat $\mathrm{di}$ atas menurut Afriana (2015), pembelajaran berbasis proyek merupakan model pembelajaran yang berpusat pada peserta didik dan memberikan pengalaman belajar yang bermakna bagi peserta didik. Pengalaman belajar peserta didik maupun konsep dibangun berdasarkan produk yang dihasilkan dalam proses pembelajaranberbasis proyek.

Selain itu penelitian lainnya mendukung penggunaan bimbingan klasikal dalam bimbingan konseling, yang telah dilakukan oleh Ardimen, Rina Yulitri, Gustina. 2019. Judul penelitian penerapan metode project-based learning untuk meningkatkan penguasaan metodologi penelitian bidang konseling. Hasil penelitian menunjukkan bahwa antusiasme dan aktivitas mahasiswa meningkat dengan penerapan metode project-based learning. Proses pembelajaran metode Project-Based Learning dapat meningkatkan penguasaan mahasiswa tentang metodologi penelitian bidang konseling, project-based learning dapat meningkatkan hasil belajar mahasiswa, khususnya metodologi penelitian kuantitatif bidang konseling, dengan project based learning mahasiswa mendapatkan pengalaman langsung dalam mengerjakan tugas sesuai dengan project yang disiapkan sebelumnya.

Kemudian setelah dilakukan intervensi resiliensi kepala sekolah taman kanak-kanak melalui layanan bimbingan klasikal berbasis $e$ learning melalui pembelajaran berbasis proyek berupa pemberian tugas mandiri berupa proyek kerja yang diberikan penjelasan dan bimbingan cara mengerjakannya, kepala sekolah diharuskan menyelesaikan secara mandiri dan diberikan batas waktu pengumpulan terakhir. $\mathrm{Hal}$ ini sepaham juga dengan pendapat Grant (2002) mendefinisikan project based learning atau pembelajaran berbasis proyek merupakan model pembelajaran yang berpusat pada peserta didik untuk melakukan suatu investigasi yang mendalam terhadap suatu topik.

Peserta didik secara konstruktif melakukan pendalaman pembelajaran dengan pendekatan 
berbasis riset terhadap permasalahan dan pertanyaan yang berbobot, nyata, dan relevan. Mendukung penelitian di atas, penelitian tentang bimbingan klasikal dan project based learning telah dilakukan juga oleh Sarleni, Rhepon. 2019. Dengan judul penelitian pendekatan saintifik dalam pelaksanaan bimbingan klasikal oleh guru bimbingan dan konseling di sekolah. Hasil penelitian mengungkapkan bahwa guru bimbingan dan konseling perlu menggunakan pendekatan secara saintifik, agar siswa semangat mengikuti kegiatan dan memahami materi layanan. sehingga siswa memperoleh pemahaman baru yang berguna bagi dirinya dalam kehidupan sehari-hari. Berdasarkan hasil di atas maka dapat diambil benang merahnya bahwa layanan bimbingan klasikal dapat digunakan dalam peningkatan resiliensi kepala sekolah berbasis e-learning di masa Covid-19. Kemudian setelah selesai kepala sekolah diberikan instrumen resiliensi kedua. Berdasarkan hasil olah data dan uji normalitas.

Berdasarkan hasil tabel 1.1 di atas dan karena jumlah sampel peneltian ini 30, artinya di bawah 50, maka peneliti memakai hasil uji normalitas Shapiro-Wilk. Maka berdasarkan tinjauan dari hasil normalitas Shapiro-Wilk menunjukan nilai signifikan $0,318>0,05$ artinya sampel penelitian berasal dari populasi yang berdistrusi normal. Kemudian diperoleh rata-rata tingkat resiliensi kepala sekolah $84,3 \%$. Secara kategori berada pada posisi baik. Resilensi adalah kapasitas seseorang mampu mengatasi masalah yang mengganggu dengan beradaptasi dan motivasi untuk berhasil menyelesaikan masalah yang sedang dihadapinya. Maka relisiliensi penting dimiliki oleh kepala sekolah. Begitu juga rendahnya tingkat resiliensi pada kepala sekolah taman kanak-kanak perlu diperbaiki, karena apabila dilihat dari harapan dan tuntutan pemerintah, maka hal tersebut akan menjadi tantangan yang bagi kepala sekolah.

Dengan meningkatkan resiliensi, manusia dapat mengembangkan ketrampilan hidup seperti bagaimana berkomunikasi, kemampuan yang realistik dalam membuat rencana hidup dan mampu mengambil langkah yang tepat bagi hidupnya (Fernanda Rojas, 2015). Hal ini sepaham dengan penelitian tentang resiliensi telah dilakukan oleh Reza Pahlevi, Dwi Yuwono Puii Sugiharto \& Muhammad Jafar (2017) yang melakukan penelitian tentang Prediksi SelfEsteem, Social Support dan Religiusitas terhadap Resiliensi. Hasil penelitian mengungkapkan bahwa terdapat hubungan yang positif dan signifikan antara self-esteem, social support dan religiusitas dengan resiliensi siswa MAN se-Kota Yogyakarta. Arah hubungan bersifat positif yang artinya bahwa semakin tinggi self-esteem, social support dan religiusitas siswa, maka semakin tinggi resiliensinya, dan apabila semakin rendah selfesteem, social support dan religiusitas siswa, maka semakin rendah juga resiliensinya.

Menurut Desmita (2013), bahwa mereka yang resiliensi, resiliensi membuat hidupnya menjadi lebih kuat. Artinya resiliensi akan membuat seseorang berhasil menyesuaikan diri dalam berhadapan dengan kondisi-kondisi yang tidak menyenangkan, pekembangan sosial, akademis, kometensi vokasional, dan bahkan dengan tekanan hebat yang inheren dalam dunia sekarang sekalipun. Sepaham dengan pendapat Desmita, Issacson menguatkan (2002:4) bahwa resiliensi berarti kemampuan untuk mengatasi kesulitan traumatis. Selain itu juga untuk merespon tekanan hidup sehari-hari secara fleksibel. Sedangkan menurut Juke $(2003,63)$ resiliensi adalah kapasitas manusiawi yang dimiliki seseorang dan berguna untuk menghadapi, memperkuat diri atau bahkan mengubah kondisi kehidupan yang tidak menyenangkan (traumatik) menjadi suatu hal yang wajar untuk diatasi. Kemudian menurut Masten (2007) resiliensi adalah ide yang mengacu pada kapasitas sistem dinamis untuk bertahan atau pulih dari gangguan.

Selain itu penelitian resiliensi dalam bimbingan konseling juga telah dilakukan oleh Novi Rizani Khomsah, Heru Mugiarso, Kusnarto Kurniawan (2018) dengan judul penelitian layanan konseling kelompok untuk meningkatkan resiliensi siswa. Hasil penelitian mengungkapkan bahwa layanan konseling kelompok dapat mempengaruhi resiliensi siswa mengenai regulasi emosi, pengendalian impuls, optimis, analisis sebab akibat, empati, efikasi diri, dan reaching out yang merupakan aspek dari resiliensi. Hal ini juga diperkuat oleh penelitian resiliensi telah dilakukan oleh Cantika 
(2012) dengan judul penelitian resiliensi pada remaja binaan bapas ditinjau dari coping stress, hasil penelitian resiliensi remaja binaan bapas dalam kategori sedang.

Sedangkan Menurut Reivich. K dan Shatte. A (2002) menjelaskan bahwa arti resiliensi itu adalah kemampuan untuk mengatasi dan beradaptasi bila terjadi sesuatu yang merugikan dalam hidupnya. Bertahan dalam keadaan tertekan sekali pun, atau bahkan berhadapan dengan kesengsaraan (adversity) maupun trauma yang dialami sepanjang kehidupannya. Jika orang memiliki resiliensi dalam dirinya, maka akan menghadapi segala permasalahan yang dialaminya dengan cara yang sehat. Mereka akan membiarkan perasaan sedih, kecewa dan berduka dalam dirinya, tetapi tidak akan membiarkan dirinya dalam keadaan seperti itu secara permanen. Hal ini juga diperkuat penelitian resiliensi juga telah dilakukan oleh Sholih, Rochani, Deasy Yunika Khairun, Ibrahim Al Hakim (2017). Judul penelitian meningkatkan resiliensi remaja melalui biblio counseling. Hasil penelitian menunjukkan biblio counseling efektif dalam peningkatan resiliensi siswa yang menjadi subjek penelitian, hal ini ditandai adanya peningkatan skor tingkat resiliensi warga belajar dan timbal balik bimbingan dalam proses pelaksanaan intervensi biblio counseling. Peningkatan skor resiliensi warga belajar mengindikasikan warga belajar sebagai subjek penelitian dapat mencapai indikator-indikator di setiap aspek resiliensi.

Selanjutnya menurut Grotberg (1995) yang menyatakan bahwa resiliensi adalah kapasitas universal yang mengizinkan seseorang, kelompok atau komunitas untuk mencegah, meminimalisasi atau mengatasi efek yang merusak dari kesulitan. Penelitian lain tentang resiliensi telah dilakukan oleh Edris Zamroni (2016) dengan judul penelitian self resilience pada konselor: konstruksi konselor tahan uji sebagai pribadi efektif dalam melayani konseli. Hasil penelitian mengungkapkan self resilience seorang konselor merupakan faktor yang bekontribusi dalam keefektifan pelayanan konseling pada konseli. Pribadi konselor efektif bisa ditunujukkan dari seberapa ketahan ujian seorang konselor dalam menghadapi masalah baik masalah yang dihadapinya sendiri maupun oleh konseli yang dilayaninya.

Adanya peningkatan relisiensi kepala sekolah taman kanak-kanak juga dipengaruhi faktor lainnya, hal ini sepaham dengan pendapat Sing dan Yu (2010) faktor-faktor resiliensi meliputi ketahanan, optimisme, kecerdikan dan tujuan. Meningkatkan resiliensi adalah tugas yang penting karena hal ini dapat memberikan pengalaman bagi manusia dalam menghadapi tantangan dan kesulitan hidup.

Kemudian berdasarkan hasil uji hipotesis untuk mengetahui keefektivan intervensi layanan bimbingan klasikal berbasis e-learning dengan pembelajaran berbasis proyek diperoleh data ada signifikansi karena berdasarkan hasil paired sample t-test diperoleh $-36,870$, artinya probalitas ini lebih kecil dari taraf signifikansi $0,005(\mathrm{t}=-36,870, \mathrm{p}<0,05)$. Artinya layanan bimbingan klasikal berbasis e-learning dengan pembelajaran berbasis proyek efektif dalam meningkatkan resiliensi kepala sekolah taman kanak-kanak. Dapat peneliti simpulkan bahwa penggunaan layanan bimbingan klasikal berbasis e-learning melalui pembelajaran berbasis proyek efektif meningkatkan resiliesi kepala sekolah taman kanak-kanak.

\section{PENUTUP}

\section{Simpulan}

Berdasarkan data hasil penelitian, dapat disimpulkan bahwa layanan bimbingan klasikal dengan pembelajaran berbasis proyek efektif meningkatkan resiliensi kepala sekolah taman kanakkanak. Hal ini dapat dilihat dari adanya perbedaan signifikan skor rata-rata resiliensi sebelum dan sesudah diberikan layanan bimbingan klasikal dengan pembelajaran berbasis proyek. Uji normalitas dengan Shapiro-Wilk (0,318 > 0,05). Teknik Analisis data dengan menggunakan statistik parametrik dengan uji paired sample t-test dengan nilai statistik $(t=.-36,870, p<0,05)$. Hasil enelitian memberikan pemahaman bahwa terdapat perbedaan resiliensi kepala sekolah sebelum dan sudah mendapatkan bimbingan klasikal dengan menggunakan model Project Based Learning. Artinya 
layanan bimbingan klasikal dengan pembelajaran berbasis proyek efektif meningkatkan resiliensi kepala sekolah taman kanak-kanak Jakarta Timur.

\section{Rekomendasi}

Berdasarkan hasil penelitian ini, dapat direkomendasikan bahwa penggunakan layanan bimbingan klasikal berbasis e-learning dapat dilakukan di masa Covid-19 untuk meningkatkan resiliensi kepala sekolah taman kanak-kanak. Kepala sekolah dapat menggunakan metode ini untuk diterapkan kepada guru di satuan pendidikannya bekerja. Guru BK dapat menggunakan metode ini pada peserta didik jenjang menengah. Bagi widyaiswara ,dosen dapat lakukan penelitian lanjutan agar diperoleh model pengembangan yang lebih luas. 


\section{DAFTAR PUSTAKA}

Ananda Hadi Elyas (2018). Penggunaan Model Pembelajaran E-Learning Dalam Meningkatkan Kualitas Pembelajaran, Jurnal Warta, 56(2) : 1-11

Afriana, Jaka. (2015). Project Based Learning (PjBL). Makalah untuk Tugas Mata KuliahPembelajaran IPA Terpadu. Program Studi Pendidikan IPA Sekolah Pascasarjana. Universitas Pendidikan Indonesia. Bandung.

Ade Kusmana. (2011). E-Learning dalam Pembelajaran, Lentera pendidikan, 14 (1) : 36-51.

Ardimen , Rina Yulitri , Gustina.( 2019). penerapan metode project-based learning untuk meningkatkan penguasaan metodologi penelitian bidang konseling. Jurnal Lentera Pendidikan, Vol. 22 No. 1 Juni 2019: $64-80$

Budiman, S. \& Arif, M. (2017). Keefektifan Bimbingan Klasikal Berbantuan Media Audio Visual Dalam Upaya Mencegah Terjadinya Pernikahan Usia Dini. Jurnal Penelitian Pendidikan Indonesia, 2(2).

Cantika Yeniar Pasudewi. (2012) Resiliensi Pada Remaja Binaan Bapas Ditinjau Dari Coping Stress. Journal of Social and Industrial Psychology, 1 (2): 14-21.

Diana Ariani. (2018). Komponen Pengembangan E-Learning, Jurnal Pembelajaran Inovatif, 1 (1) : 58-65.

Desmita. (2013). Psikologi Perkembangan. Bandung : PT Remaja Rosdakarya.

Dameis Surya Anggara dan Saiful Anwar.(2017). Statistika Pendidikan. Tangerang: Unpam Press.

Entin Martini, Wahyu Nanda Eka Saputra , Abdul Malik. (2018). Peningkatan Ketrampilan Eksplorasi Karir Melalui Bimbingan Klasikal Teknik Project Based Learning Pada Siswa Kelas X BDP 3 Di SMK Negeri 1 Kebumen. Prosiding pendidikan profesi guru universitas ahmad dahlan yogyakarta. Hal 556-575.

Edris Zamroni. (2016) . Self Resilience Pada Konselor: Konstruksi Konselor Tahan Uji Sebagai Pribadi Efektif Dalam Melayani Konseli, G-COUNS Jurnal Bimbingan dan Konseling, 1 (1) : 24-36.

Fernanda Rojas, L. (2015). Factors affecting academic resilience in middle school students : A case study. Gist Education And Learningresearch Journal, 11(11), 63- 78.

Grant, M.M. (2002). Getting A Grip of Project Based Learning : Theory, Cases and Recomandation. North Carolina : Meredian A Middle School ComputerTechnologies. Journal Vol. 5.

Goodman, Brandon and Stivers, J. (2010).. Project-Based Learning. Educational Psychology. ESPY 505.

Grotberg, E. H. (1995). A guide to promoting resiliency in children: Strengthening the human spirit. Early Chidhood Development: Practice And Reflections, 8.

Horton, Willian dan Horton, Katherine. (2003). E-learning Tools and Technologies: a costumer guide for trainers, teacher, educators and instructional designers. USA: Wiley Publishing, Inc.

https://kesehatan.kontan.co.id/news/inilah-5m-untuk-pencegahan-covid-19-dan-bedanya-dengan-3m-serta-3t

Intan Mutia, (2013). Kajian Penerapan E-Learning Dalam Proses Pembelajaran Di Perguruan Tinggi, Faktor Exacta, 6(4): 278-289.

Isa Bahroni, Riyadi Purwanto. (2018). Aplikasi Pembelajaran (E-learning) Mengenal Huruf Hijaiyah bagi Anak-anak Berbasis Mobile untuk Mendukung Pembelajaran Secara Mandiri, Jurnal Edukasi dan Penelitian Informatika, $4(2): 163-172$ 
Isyarotullatifah (2019). Pengembangan Konten E-Learning Ips Berbasis Self Regulated Learning, Jurnal Visi Ilmu Pendidikan, 11 (2) : 1-11.

Issacson, B. (2002). Characteristics And Enhancement Of Resiliency In Young People. A Research Paper. The Graduate School,University of Wisconsin-Stout.

Kamarga, Hanny.( 2002). Belajar Sejarah melalui e-learning; Alternatif Mengakses Sumber Informasi Kesejarahan. Jakarta: Inti Media.

Lestari, Tutik.( 2015).Peningkatan Hasil Belajar Kompetensi Dasar Menyajikan Contoh-Contoh Ilustrasi Dengan Model Pembelajaran Project Based Learning dan Metode Pembelajaran Demonstrasi Bagi Siswa Kelas XI Multimedia SMK Muhammadiyah Wonosari. Skripsi Program Studi Pendidikan Teknik Informatika Fakultas Teknik Universitas Negeri Yogyakarta.

Mastura, M., \& Santaria, R. (2020). Dampak Pandemi Covid-19 Terhadap Proses Pengajaran Bagi Guru dan Siswa. Jurnal Studi Guru Dan Pembelajaran, 3(2), 289-295.

Masten, A. S. (2007). Resilience in developing systems: Progress and promise as the fourth waves rises. Development and Psychopatology. 19. 921- 930. doi: 10.1017/S0954579407000442

Numiek Sulistyo Hanum. (2013). Keefektifan E-Learning Sebagai Media Pembelajaran (Studi Evaluasi Model Pembelajaran E-Learning SMK Telkom Sandhy Putra Purwokerto), Jurnal Pendidikan Vokasi, 3(1): 90-102.

Novi Rizani Khomsah, Heru Mugiarso, Kusnarto Kurniawan (2018). Layanan Konseling Kelompok untuk Meningkatkan Resiliensi Siswa. Indonesian Journal of Guidance and Counseling: Theory and Application, 7 (2): 46-53.

Reza Pahlevi1, Dwi Yuwono Puji Sugiharto1 \& Muhammad Jafar (2017). Prediksi Self-Esteem, Social Support dan Religiusitas terhadap Resiliensi. Jurnal Bimbingan Konseling, 6 (1): 90-93.

Reivich, K., Shatte A.(2002). The Resilience Factor Tujuh Key To Finding Your Inner Strength And Overcoming Life's Hurdles. New York : Three Rivers Press

Schoon, I. (2006). Risk and Resilience, Adaptation in Changing Times. Cambridge University Press. New York

Sholih1 , Rochani2, Deasy Yunika Khairun3 Ibrahim Al Hakim4. (2017). Meningkatkan Resiliensi Remaja Melalui Bibliocounseling, 2 (1): 51-61.

Silahuddin (2015). Penerapan E-LEARNING dalam Inovasi Pendidikan, Jurnal Ilmiah CIRCUIT, 1 (1) : 48-59.

Suharyanto dan Adele B.L Mailangkay. (2016). Penerapan e-learning sebagai alat bantu mengajar dalam dunia pendidikan, Jurnal Ilmiah Widya, 3 (4) : 17-21.

Tafiardi. (2005). Meningkatkan Mutu Pendidikan Melalui E-Learning, Jurnal Pendidikan Penabur, 4.(4): 87.

Suryahdikusumah, A.R \& Arizona. (2018). Project Based Learning Untuk Mengembangkan Kreativitas Mahasiswa Merancang Media Informasi Bk Melalui Media Sosial. Journal of Innovative Counseling : Theory, Practice \& Research, Vol.2, No.2, Agustus 2018, 94-100 Available online: http://journal.umtas.ac.id/index.php/innovative_counseling.

Sarleni, Rhepon. (2019). pendekatan saintifik dalam pelaksanaan bimbingan klasikal oleh guru bimbingan dan konseling di sekolah. Jurnal Bimbingan dan Konseling Borneo, 1(2) 2019, 42-48.

Supriyo. (2010). Teknik Bimbingan Klasikal. Swadaya Publishing.

Singh, Kamlesh dan Yu, Xiao-nan. (2010). Psychometric Evaluation of the Connor-Davidson Resilience Scale (CDRISC) in a Sample of Indian Students. Journal of Psychology, 1(1): 23-30 (2010). 
Wirda Hanim, Michiko Mamesah, Rani Romatua Anzelyna. (2018). Pengaruh Bimbingan Klasikal dengan Model Project Based Learning Untuk Meningkatkan Tanggung Jawab Siswa (Studi Eksperimen Siswa Kelas X II Audio Video 2 SMKN 5 Jakarta). Insight : jurnal bimbingan dan konseling 7 (1) Juni 2018, hal 56-67.

Winkel, W.S. Hastuti, M. M Sri.2010. Bimbingan Konseling di Institusi Pendidikan. Yogjakarta: PT Media Abadi. 